\title{
High-quality journalism in the face of Donald Trump's theory of electoral fraud: the information strategy of the media in the 2020 US presidential election
}

\author{
Concha Pérez-Curiel; Ricardo Domínguez-García; Ana-María Velasco-Molpeceres
}

Nota: Este artículo se puede leer en español en:

http://www.profesionaldelainformacion.com/contenidos/2021/nov/perez-dominguez-velasco_es.pdf

How to cite this article:

Pérez-Curiel, Concha; Domínguez-García, Ricardo; Velasco-Molpeceres, Ana-María (2021). "High-quality journalism in the face of Donald Trump's theory of electoral fraud: the information strategy of the media in the 2020 US presidential election". Profesional de la información, v. 30, n. 6, e300619.

https://doi.org/10.3145/epi.2021.nov.19

Manuscript received on $26^{\text {th }}$ April 2021 Accepted on $31^{\text {th }}$ July 2021

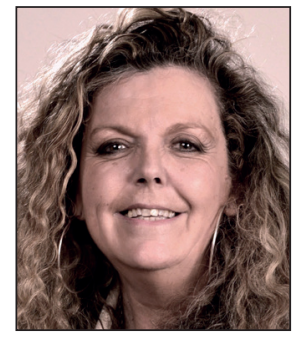

Concha Pérez-Curiel $\square$ https://orcid.org/0000-0002-1888-0451

Universidad de Sevilla

Facultad de Comunicación

Departamento de Periodismo II

Avda. Américo Vespucio, 27

41092 Sevilla, Spain

cperez1@us.es

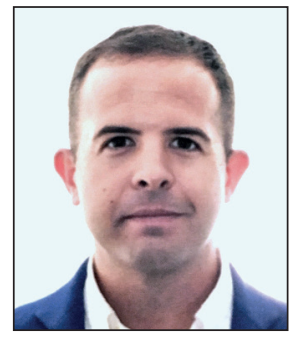

Ricardo Domínguez-García https://orcid.org/0000-0001-7325-1861

Universidad de Sevilla

Facultad de Comunicación

Departamento de Periodismo II

Avda. Américo Vespucio, 27

41092 Sevilla, Spain

ricdomgar@alum.us.es

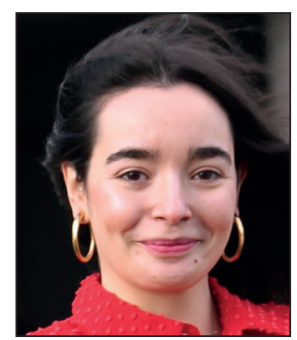
Ana-María Velasco-Molpeceres https://orcid.org/0000-0002-0593-0325
Universidad de Valladolid y UEMC
Facultad de Filosofía y Letras
Plaza campus universitario, $\mathrm{s} / \mathrm{n}$
47011 Valladolid, Spain
anamaria.velasco.molpeceres@uva.es

\begin{abstract}
The institutional political crisis is posited to be the great risk to societies in the twenty-first century. The instability of democracy, increasing misinformation during electoral processes, and distrust by citizens are facts that are confirmed by studies such as The Economist Intelligence Unit (2018) or Freedom in the World (2018). In the context of the most recent US election (3-N-2020), President Donald Trump activated a dialog focused on the denunciation of electoral fraud that mobilized the masses and culminated in an assault on the Capitol. In parallel, Twitter has endorsed the role of journalism (@ABC, @ AP, @CBSNews, @CNN, @FoxNews, @NBCNews, and @Reuters) as a gatekeeper to lies on the Internet. The objective of this study is to determine how the media treated the electoral process from their Twitter accounts, analyze which strategies they adopted to combat Trump's fallacy, and confirm the extent to which they contributed to the spread of this conspiracy theory. Using a general sample of tweets $\left(n_{1}=3,577\right)$, we applied a comparative content analysis methodology with a triple (quantitative-qualitative-discursive) approach based on the use of keyword indicators $\left(n_{2}=34,430\right)$. The results confirm that the media offered verified content on the electoral process, used various sources, and avoided reproducing Donald Trump's delegitimization discourse. In general, they fought together against the theory of electoral fraud, misinformation, and polarization of citizens, factors that have defined a scenario of doubt about the future of democracy.
\end{abstract}

\section{Keywords}

Political communication; Elections; Disinformation; Public sphere; Media; Fraud; Political polls; Democracy; Trump; Twitter; Journalism; Fake news; United States; USA; Political discourse; Political crisis; Fallacies; Conspiracy theory; Electoral processes. 
Funding

Communication \& Social Sciences research group (SEJ-619) of the University of Seville.

Acknowledgement

Statistical measurement group of Political and Economic Journalism of the University of Seville.

\section{Introduction}

The most recent US election highlighted the disaffection of citizens with public institutions (Schulte-Cloos; Leininger, 2021; Bakker; Jolly; Polk, 2020). This reopened the debate on the effects of disinformation on politics and the risks for representative democracy (Levitsky; Ziblatt, 2018; Mounk; 2018). Opinion polls (Balz; Clement; Guskin, 2021; Pew Research Center, 2020; YouGov for The economist, 2020) have revealed that $70-80 \%$ of Republican voters believe that Joe Biden's victory was the result of electoral fraud. Donald Trump's campaign, from the first face-to-face debate to the official proclamation of the Democratic candidate as president, has been supported by a discourse denouncing and delegitimizing the election. The culmination of this was the incidents surrounding the assault on the Capitol (6 January 2021) by a fraction of the Republican electorate (The New York Times, 2021), which became a media event of global interest.

Various arguments have been used to explain this event. Polarization (Neudert; Marchal, 2019) or the use of lies on social networks (Crilley; Gillespie, 2019), with consequences for citizens (Bennett; Pfetsch, 2018), are influencing factors. Added to these is Trump's use of cyber-rhetoric, a strategy that characterized the 2016 campaign and has been a common feature of his mandate (Pérez-Curiel; Limón-Naharro, 2019). The leader has shown evidence of an authoritarian style and an ability to publish biased messages on race, gender, foreign policy, and attacks on the media in line with extreme right-wing populism (Manfredi-Sánchez; Amado-Suárez; Waisbord, 2021; Waisbord, 2018; De-la-Torre, 2018).

In the most recent context, this candidate, who was voted for by more than 74 million US citizens in the last election (CNN, 2020), has constructed a narrative on Twitter that is supported by a rhetoric of simplicity, emotion, popular appeal, and falsehood (Fuentes-Rodríguez, 2020). To combat such misinformation, digital platforms have proposed a design for a plan of action against the uncontrolled use of false messages (Panetta, 2017). The climax of this was reached when Twitter decided to permanently deactivate Trump's account, claiming a provocative attitude and levels of falsehood that exceeded those during previous elections (Roth, 2018). This result stemmed from a previous announcement on the official Twitter blog (Gadde; Beykpour, 2020) warning that action would be taken against anyone using the network to manipulate or interfere with elections or other civil processes. Based on this policy, Twitter supports the work of certain generalist media outlets ( $A B C$ News, Associated Press, CBS News, CNN, Decision Desk HQ, Fox News, National Election Pool, NBC News, and Reuters), promotes this alliance against lies, and advocates trust in the information they disseminate about elections. In this way, journalism is confirmed as a bastion against disinformation and a weapon against falsehood, in the face of the confusion exhibited by the electorate according to public opinion polls (CNN, 2020).

Under the hypothesis that the media should encourage a strategy on Twitter to dismantle Trump's fraud discourse by providing verified information on the electoral process, as the main tool to address disinformation, the following objectives are proposed:

01: Use Twitter accounts to determine the topics, sources, and keywords used by the media to report on the electoral process in the USA.

O2: Analyze the strategies of the media to counteract Donald Trump's electoral fraud discourse after the election.

O3: Determine whether the media reproduce or prevent the dissemination of the theories of delegitimization and conspiracy of the leader in their messages published on Twitter.

\section{Influence of cyber-populism, leadership, and public mobilization}

The effects of platformization (Smyrnaios; Rebillard, 2019; Gerbaudo, 2018; Lockwood; Mooney, 2018) and the influence of misinformation on social networks (Crilley; Gillespie, 2019) have generated an environment of confusion among citizens that reached its maximum level during the election in the USA. Public opinion pools (Pew Research, 2020) with 13,568 respondents, as well as other polls published by the media (Balz; Clement; Guskin, 2) have revealed that a high percentage of the population questions the electoral result and indicate that

"6 out of every 10 Americans believe that Biden won the election legitimately, whereas 7 out of 10 Republicans claim that he was not elected legitimately." 
These polls, carried out more than two weeks after election day, reveal a clear division between the supporters of the two candidates regarding the fidelity of the vote counting process.

The results demonstrate that Trump voters, who were already skeptical of the vote counting data, have become much more skeptical since Biden's victory. Although a majority of respondents (59\%) consider that the electoral process was handled correctly, only a fraction of Trump supporters (21\%) believe in the procedure. Likewise, the report highlights that a majority of voters (62\%) define Trump's behavior as excellent or good, while less than half (31\%) give him a positive evaluation after the election. This snapshot confirms, on the one hand, the distrust of some citizens toward the procedure that ratified the victory of Biden, and on the other, a reaction of the majority of those surveyed against the behavior of the Republican candidate after the election.

Meanwhile, other studies (Jones, 2021) have reported a loss of support for Trump with respect to other American presidents in the post-election period (-12 points), with factors such as the delegitimization of the election, the effects of the assault on the Capitol (January 2021), and the second impeachment process (February 2021), notwithstanding the consequences of his management of the Covid-19 crisis.

An analysis of the antecedents indicates the rhetorical use of language as Trump's strategy to construct a narrative tinged with far-right populism (Mudde, 2016). Comparison of the discourse in the two presidential elections in which he has participated as a candidate reveals a rejection of the policies of globalization, integration, and the establishment, of supranational entities such as the European Union (Mammone, 2009), and of groups such as immigrants and refugees, or Muslim culture (Wodak, 2015). In addition, one should consider the dynamics of Twitter, which favors the spread of false messages and hate speech, thereby generating informational disorder (Ott, 2017). Content that is championed by antidemocratic viewpoints and imitates the work of the media and accredited professionals can become viralized (Wooley; Howard, 2016). These characteristics provide the backdrop to a leader who shows contempt for the press as an enemy (Waisbord; Amado, 2017), normalizing the erosion of independent journalism with a consequent deterioration of democracy (Bennet; Livingston, 2018).

However, the feature differentiating these two processes is defined by the attack on the electoral system, using a narrative in which the theories of conspiracy and electoral fraud converge (Fajardo-Trigueros; Rivas-de-Roca, 2020), thus questioning the legitimacy of the result. This relies on a spectrum of strategies that intensify disinformation, propaganda, and hoaxes in a context of crisis (Pérez-Curiel; Rivas-de-Roca, 2021), thus reigniting the debate on the role of journalism in terms of social responsibility.

\section{Journalistic codes of quality: challenges and risks in the face of misinformation}

Information is a key element in the functioning of a healthy democracy. The provision of high-quality information to citizens enables them to form an opinion and participate politically. Indeed, this is the primary purpose of journalism (Kovach; Rosenstiel, 2007). However, the media system has been affected by a proliferation of channels and platforms, the multiplication of information providers, an abundance of communication media, and increased competition (Casero-Ripollés, 2018). These factors condition the work of journalists as gatekeepers to disinformation and increase the disaffection of public opinion with institutions themselves (Waisbord, 2018).

Journalistic work, which is key for the public to understand reality and strengthen the links between information and democracy (Casero-Ripollés, 2020), is witnessing a moment of profound transformation that requires the promotion of the hybridization and complementarity of traditional and digital media (Chadwick, 2017; Dutta-Bergman, 2004). In this scenario, in collaboration with social platforms, one of the objectives of the media when reporting on the 2020 US electoral process was to strengthen a common information policy on social networks, capable of articulating the public sphere (Habermas, 2006) and, in turn, disarticulate the discourse of conspiracy and lies (Kaiser, 2020).

During the 2016 election, the Washington Post gave Trump the maximum score on their dishonesty scale (four "Pinocchios"), observing that 64 of his statements were totally false, while other newspapers such as USA Today, The Boston Globe, The Wall Street Journal, and The New York Times complained about the candidate's account on Twitter (Pérez-Curiel; Limón-Naharro, 2019) but failed to impact the electoral results. During the 2020 election, a group of media and news agencies (@ABC, @AP, @CBSNews, @CNN, @FoxNews, @NBCNews, @Reuters) promoted journalistic quality as a fundamental principle from their Twitter accounts (Pellegrini; Múgica, 2006). According to this dynamic, information prevails over interpretation and opinion in the treatment of issues, source checking is increased, elements of political bias that position the media in favor or against Trump are avoided, while a discourse based on facts is favored over declarative journalism.
Twitter warned that action would be taken against anyone using the network to manipulate or interfere with elections or other civil processes. Based on this policy, Twitter supports the work of certain generalist media outlets 
Ultimately, these are ethical codes (Romero-Rodríguez; De-Casas-Moreno; Torres-Toukoumidis, 2016) that weaken Trump's discourse of electoral fraud in a society that is exposed to increasing misinformation (Bennett; Livingston, 2018), and mistrust in traditional media, because of the effects of political polarization and the fragmentation of a media environment offering wide choice (Van-Aelst et al., 2017). The latest post-election polls (Jones, 2021) highlight a loss of support for the Republican candidate among the electorate, related to factors such as the delegitimization of the election, the effects of the assault on the Capitol (January 2021), and the second impeachment process (February 2021), notwithstanding the consequences of the management of the Covid-19 crisis. All of this occurred in a climate of disinformation that permeated the electoral context from the beginning and favored the opportunity for conventional media to converge with digital media, to reconnect with the audience and offer verified information on public affairs.

In this dilemma, an effect opposite to what was hitherto known as confirmation bias theory can occur. According to this principle, users believe in false information circulating on the Internet as a way of confirming their own beliefs, without a rational analysis of the facts (Pennycook; Rand, 2018). In addition, they trust the editorial lines of ideologically related media that fit with their preconceived ideas while discarding other information (Sanz-Blasco; Carro-de-Francisco, 2019).

In complex and risky news scenarios linked to health and political crises such as those that defined the US election, the primacy of traditional media calls into question theories about the reduction of their influence in the current political information environment. The media thus recover their right to be heard, recovering part of their journalistic authority (Carlson, 2017), while the public opts for established information sources with a long history (Esser et al., 2012) that exhibit truthfulness and reliability (Palau-Sampio; Gómez-Mompart, 2015). Far from dispensing with social networks, the media have opted to join a mode of reporting that maintains ethical and quality principles as a differential element with respect to the disinformation of political leaders, anonymous users, and new mediatized voices (Pérez-Curiel; Velasco-Molpeceres, 2020) that pose a challenge to journalism.

\section{Methodology}

In this scenario of profound changes in the media system and the behavior of public opinion in the face of disinformation, it is important to determine the role that journalism played during the US election process, which production patterns prevailed, and the extent to which they contributed to the dissemination of or counteracting Donald Trump's discourse on conspiracy and electoral fraud as well as the effects on democratic stability.

Starting from this approach, the following research questions are thus posed:

RQ1. How prominent is Trump's theory of electoral fraud in media coverage on Twitter?

RQ2. What indicators of journalistic quality do the media apply to report on the US election process?

RQ3. To what extent did media activity on Twitter help spread or defuse Trump's conspiracy theory?

Considering these three premises, a quantitative-qualitative (Silverman, 2016; Krippendorff, 2004) and discursive (Flowerdew; Richardson, 2017; Van-Dijk, 2015) methodology of comparative content analysis is applied, based on keyword indicators (Vázquez-Cano; Fombona; Bernal, 2016).

The social network Twitter was chosen to carry out this research because of its high relevance for political communication during election periods (Alonso-Muñoz; Marcos-García; Casero-Ripollés, 2016; D’Heer; Verdegem, 2015) and because it is considered to be a key resource for the viralization of Donald Trump's propaganda

The Washington Post gave Trump the maximum score on their dishonesty scale (four "Pinocchios"), observing that 64 of his statements were totally false (Ott, 2017; Enli, 2017). The tracking of tweets was carried out using the T-Hoerder17 application (Congosto; Basanta-Val; Sánchez-Fernández, 2017). This package consists of a set of open-source software resources that both enables the downloading and processing of information from Twitter and facilitates the use of analysis tools and visualization for networks. The statistical software used for the data analysis is IBM SPSS (version 25). Intercoder reliability is calculated using Scott's Pi formula, reaching an error level of 0.98 .

The measurement process started with an analysis of the messages of those media considered by Twitter to be accredited sources of information for monitoring and scrutiny of the US electoral process:

- ABC News (@ABC)

- Associated Press (@AP)

- CBS News (@CBSNews)

- CNN(@CNN)

- Fox News (@FoxNews)

- NBC News (@NBCNews) and

- Reuters(@Reuters). 
The selection criteria for the sample were determined on the basis of the decision of the social network Twitter to address the increase of misinformation during the US presidential election. To achieve this, Twitter selected a series of US media as official sources regarding the process of the electoral vote counting process (Gadde; Beykpour, 2020). These are generalist media that have teams of journalists, political scientists, and sociologists who monitor and screen the vote counting, as well as portals exclusively specialized in polls, such as Decision Desk HQ and the National Election Pool. However, the latter websites were finally excluded from the measurements herein, since they are not considered to be general information media.

According to a report published by Pew Research Center in 2021 on the news coverage during the first 60 days of Joe Biden's presidency, the ideological composition of the selected media audiences is very close to the center (Table 1). However, the profile of Fox News viewers is clearly conservative or with a Republican tendency compared with the other media outlets, while $C N N$ viewers identify themselves with a liberal or Democratic position, and $A B C$ News, CBS News, and NBC News have mixed audiences. Regarding the agencies (Associated Press and Reuters), it must be borne in mind that these are international organizations with an ethical code that includes the objectivity and truthfulness of the information that they provide to a set of media with diverse ethical, political, and ideological bases (Caldera-Serrano; Nuño-Moral; Zapico-Alonso, 2004).

To analyze the response of these media to tweets focused on the delegitimization of the election result, those publications that used the word "Trump" or mentioned his personal account (@realdonaldtrump) were selected. The time frame extends from the date of the speech given by the Republican candidate on the night of the presidential election, in which he refused to accept his defeat (04/11/2020 at 02:20 EST), until the official proclamation of Joe Biden as President-Elect of the USA (07/01/2021 at 3:40 AM EST).

The general sample of tweets $\left(n_{1}=3,577\right)$ was subjected to a first thematic categorization, yielding a specific sample $\left(n_{2}\right.$ $=2,222$ ) that included only messages related to the electoral process. From these constants, a coding manual was designed, including ten variables (Table 2) that correspond to the threefold comparative content analysis and enabling, using the SPSS statistical program, the generation of contingency or crossover and frequency tables.

For the quantitative analysis, a series of simple quantification variables were used, grouped into indicators of the dissemination of the tweets, such as the number of retweets, the number of likes, and the number of replies. To calculate the capacity for viralization and the influence of the tweets, a formula applied in previous studies (Carrasco-Polaino; Villar-Cirujano; Tejedor-Fuentes, 2018), which assigns twice the value to retweets compared with likes, was chosen. This is motivated by the fact that Twitter gives greater visibility to retweets and increases their dissemination capacity by presenting them on the timeline of the person who published it. This formula is based on the sum of likes and retweets multiplied by 2 , divided by the number of tweets published.

Viralization capacity $=$ (SUM of retweets * $2+$ SUM of likes) / SUM of tweets published

On the basis of this equation for this first metric, a second formula was established by dividing the number of replies by the number of tweets. The aim here is to measure the conversation thread of the audiences with respect to the messages published by the media on their Twitter accounts.

Ability to generate debate $=$ SUM of replies $/$ SUM of tweets

For the qualitative analysis, variables related to the theme and focus of the tweets were included. Thus, on the basis of a first reading of all the published tweets and considering the most frequently repeated brands or the presence of keywords, a catalog of specific topics linked to the electoral process was drawn up (vote counting, legal appeals, Electoral College, transfer of power, political parties, riots, confrontation with the media, runoff election in Georgia, and others). In addition, the angle of the journalistic activity was analyzed, as well as whether the content of the texts was mainly informative, in- 
terpretive, or opinion. Moreover, the construction of the message was also taken into account, as well as whether it was supported by information produced by the media itself or by statements from experts, Donald Trump, Joe Biden, or other political leaders. In addition, the type of bias inherent to the information on Trump was analyzed, understanding this as the tendency or inclination of the media against a particular political cause (Gunter, 1997), and it was determined whether the position adopted by the media was positive, negative, or neutral.
Far from dispensing with social networks, the media have opted to join a mode of reporting that maintains ethical and quality principles as a differential element with respect to the disinformation of political leaders, anonymous users, and new mediatized voices that pose a challenge to journalism

Finally, discursive analysis was carried out on the basis of the linguistic methodology of lemmatization (Vázquez-Cano; Fombona; Bernal, 2016; Mancera-Rueda; Pano-Alamán, 2014; Bernicot et al., 2014), using keywords (Sánchez-Saus, 2018; Duque, 2014), selected and combined using AntConc software (Anthony, 2021). This procedure consists of grouping under an inflected form (lemma) all the possible forms of the same word (plural, feminine, and conjugations). In addition, a stoplist was applied to exclude frequent words, which lack semantic significance and bias, such as prepositions, conjunctions, determiners, or auxiliary verbs. From the specific sample $(2,222$ tweets), a general corpus of terms $(34,430)$ was constituted, from which keywords presenting a higher frequency in the tweets (100) were selected and their different combinations studied. This procedure enabled us to organize the sample by thematic categories, identify the language codes used by the media, and determine the possible equivalence with the terms used by Donald Trump on Twitter.

\section{Analysis and discussion of results}

The statistical analysis of the data was structured based on the metric indicators of the dissemination of messages, indicators of thematic qualification, and indicators of discursiveness, considering the use of keywords. The process involved two phases:

\section{Phase 1: General sample descriptors}

The general sample of the study comprised 3,577 tweets about Donald Trump, published from election night until the official proclamation of Joe Biden as President-Elect of the USA and distributed among the seven analyzed media: $A B C$ (634 tweets, $17.7 \%$ of the total), Associated Press (235, 6.6\%), CBS News (657, 18.4\%), CNN (632, 17.7\%), Fox News (220, $6.2 \%), N B C$ News $(626,17.5 \%)$, and Reuters $(626,17.5 \%)$. These figures confirm that the sampling was representative, enabling comparisons to be made between the different profiles and results to be obtained at the global level.

The data indicate less activity from the $A P(6.6 \%)$ and Fox News (6.2\%) accounts compared with the others composing the studied corpus. This effect is more notable in the case of the Fox News television network, which generally shows significant levels of activity on this social network. Beyond issues related to journalistic criteria, the Fox News data could be related to Donald Trump's criticism of this media group. In the final stage of the election process, this media outlet with a conservative ideology and close to the candidate in previous elections joined the recognition of Biden's victory, thus rejecting the theory of electoral fraud of the erstwhile president.

Regarding the general theme of the tweets published about Trump (Table 3), note that these media outlets focused their attention on the US electoral process (62.7\%), overshadowing the rest of the US federal government's political agenda. It is relevant that, in the midst of the pandemic and before the start of the vaccination rollout, news related to Donald Trump's management of Covid-19 only accounted for $9.4 \%$ of the publications by the media. Along the same lines, issues of public interest to citizens, such as security $(5.9 \%)$ or the economy

(3.7\%), and others typical of the White House's everyday agenda, such as international relations (6.1\%), were relegated to the background. It is thus confirmed that the studied media accounts on Twitter emphasized the issue of the presidential election, the verification of the results, and the appointment of the new president, in a context, compared with other elections, marked by the delegitimization attempt promoted by Trump.

Crossing the general theme variable with each of the studied media reveals that the $A B C(76.2 \%)$ and $C B S(75.2 \%)$ television networks provided greater coverage of the electoral process, while the Associated Press agency (45.5\%) dedicated least space to this topic. Another striking aspect is that the Reuters agency is the medium that gave the greatest importance to international relations (13.9\%), while the Associated Press focused on information related to Covid-19 (15.3\%) and safety (11.1\%). It follows that news agencies, given their informational function, select themes beyond the electoral battle, being related to the management and involvement of Donald Trump in other government affairs. 
Table 3. Categorization of general themes according to the communication medium

\begin{tabular}{|c|c|c|c|c|c|c|c|c|c|}
\hline \multirow[b]{2}{*}{ General subject } & \multicolumn{9}{|c|}{ Medium } \\
\hline & & ABC News & $A P$ & CBS News & $C N N$ & Fox News & NBC News & Reuters & Total \\
\hline \multirow{2}{*}{ Electoral process } & Count & 483 & 107 & 494 & 311 & 133 & 321 & 394 & 2,243 \\
\hline & $\%$ within medium & $76.2 \%$ & $45.5 \%$ & $75.2 \%$ & $49.2 \%$ & $60.5 \%$ & $56.0 \%$ & $62.9 \%$ & $62.7 \%$ \\
\hline \multirow{2}{*}{ Security } & Count & 28 & 26 & 28 & 44 & 8 & 50 & 28 & 212 \\
\hline & $\%$ within medium & $4.4 \%$ & $11.1 \%$ & $4.3 \%$ & $7.0 \%$ & $3.6 \%$ & $8.7 \%$ & $4.5 \%$ & $5.0 \%$ \\
\hline \multirow{2}{*}{ Economy } & Count & 13 & 8 & 16 & 27 & 16 & 12 & 41 & 133 \\
\hline & $\%$ within medium & $2.1 \%$ & $3.4 \%$ & $2.4 \%$ & $4.3 \%$ & $7.3 \%$ & $2.1 \%$ & $6.5 \%$ & $3.7 \%$ \\
\hline \multirow{2}{*}{ Covid-19 } & Count & 61 & 36 & 43 & 64 & 20 & 55 & 58 & 337 \\
\hline & $\%$ within medium & $9.6 \%$ & $15.3 \%$ & $6.5 \%$ & $10.1 \%$ & $9.1 \%$ & $9.6 \%$ & $9.3 \%$ & $9.4 \%$ \\
\hline \multirow{2}{*}{ Environment } & Count & 4 & 7 & 7 & 20 & 0 & 12 & 10 & 60 \\
\hline & $\%$ within medium & $0.6 \%$ & $3.0 \%$ & $1.1 \%$ & $3.2 \%$ & $0 \%$ & $2.1 \%$ & $1.6 \%$ & $1.7 \%$ \\
\hline \multirow{2}{*}{$\begin{array}{l}\text { International } \\
\text { relations }\end{array}$} & Count & 16 & 12 & 24 & 43 & 6 & 29 & 87 & 217 \\
\hline & $\%$ within medium & $2.5 \%$ & $5.1 \%$ & $3.7 \%$ & $6.8 \%$ & $2.7 \%$ & $5.1 \%$ & $13.9 \%$ & $6.1 \%$ \\
\hline \multirow{2}{*}{ Others } & Count & 29 & 39 & 45 & 123 & 37 & 94 & 8 & 375 \\
\hline & $\%$ within medium & $4.6 \%$ & $16.6 \%$ & $6.8 \%$ & $19.5 \%$ & $16.8 \%$ & $16.4 \%$ & $1.3 \%$ & $10.5 \%$ \\
\hline \multirow{2}{*}{ Total } & Count & 634 & 235 & 657 & 632 & 220 & 573 & 626 & 3,577 \\
\hline & $\%$ within medium & $100 \%$ & $100 \%$ & $100 \%$ & $100 \%$ & $100 \%$ & $100 \%$ & $100 \%$ & $100 \%$ \\
\hline
\end{tabular}

\begin{tabular}{|l|c|c|c|}
\hline \multicolumn{4}{|c|}{ Chi-squared tests } \\
\hline & Value & Df & Asymptotic significance (bilateral) \\
\hline Pearson chi squared & $419,194^{\mathrm{a}}$ & 36 & 0 \\
\hline Likelihood ratio & 429,284 & 36 & 0 \\
\hline Linear to linear association & 27,085 & 1 & 3,577 \\
\hline N of valid cases & & \\
\hline a Two entries (4.1\%) are expected to have a count less than 5. The minimum expected count is 3.69. \\
\hline
\end{tabular}

The study of the tweets related to information about Donald Trump published by the media each day within the time sample reveals a progressive decrease in information related to Trump and the electoral process (Graph 1). A first stage is observed (from 04-11-20 to 13-11-20) in which the political turmoil surrounding vote counting attracted the attention of the media. However, in a second stage, once the electoral results were confirmed in the different states and Joe Biden's victory was consolidated, the media decided to pay more attention to other issues related to the political management of the White House. In fact, during the second half of December, information on the electoral process was practically absent.

This trend strengthened after the Electoral College vote $(14 / 12 / 20)$ and was only disrupted in the days $(4 / 1 / 21$ to $6 / 1 / 21)$ before the formal proclamation in Congress of Joe Biden as President-Elect of the USA. The data also reflect the extensive media coverage surrounding the assault on the Capitol in Washington, DC, a conflict that highlighted a crisis of the US constitutional system itself and can be considered to mark the end of the Trump presidency. In short, the results highlight that, despite the erosion he suffered after his electoral defeat and his attempt to delegitimize the results, Donald Trump continued to be a key figure on the US media scene, since except

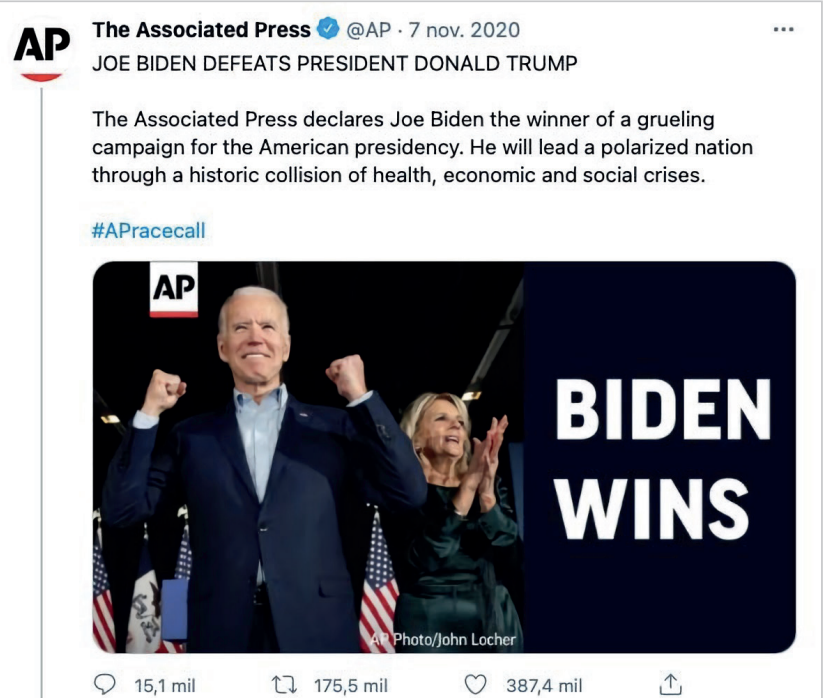

Image 1. Tweet from the $A P$ agency about the proclamation of Biden's victory. https://twitter.com/AP/status/1325112826072084480 


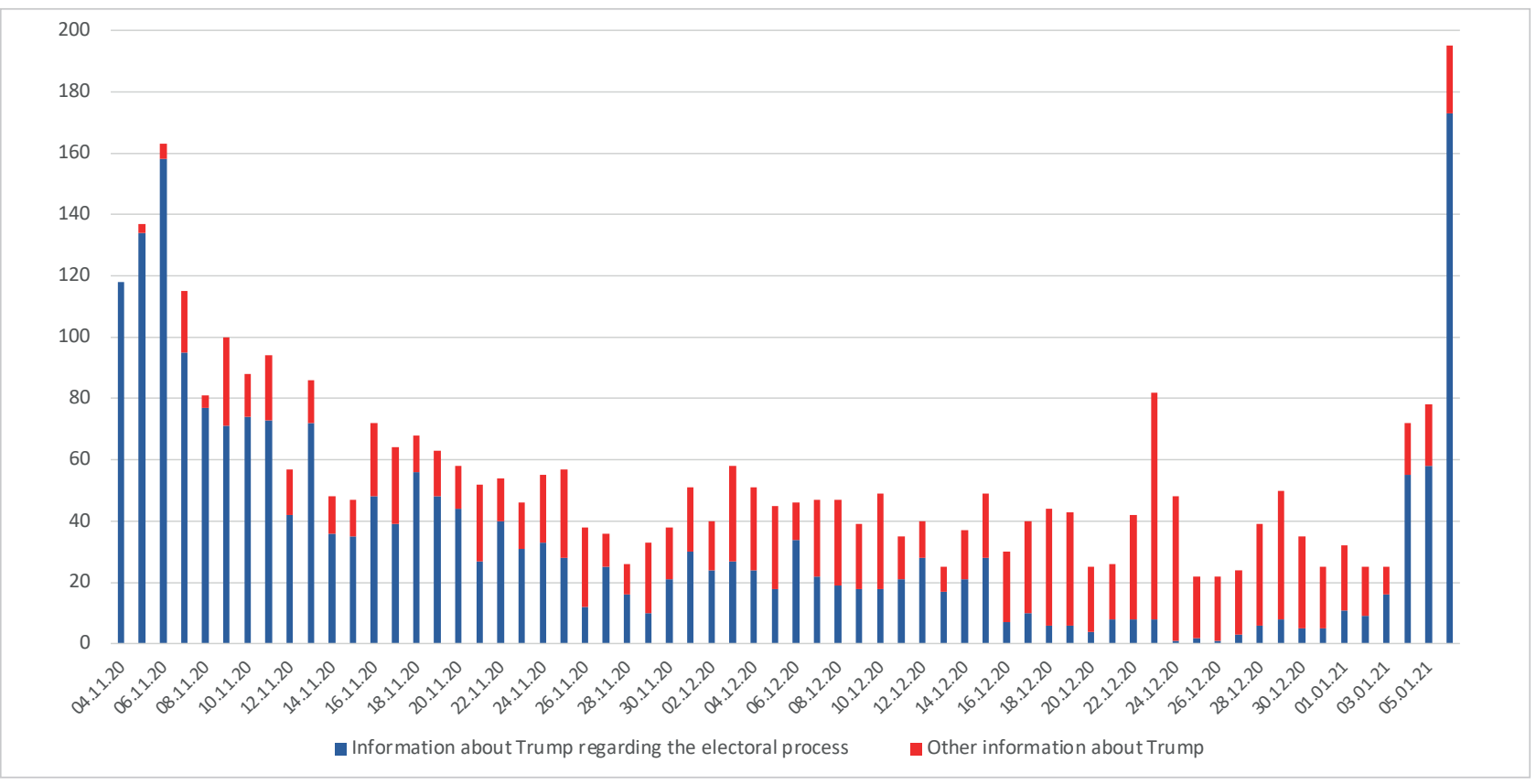

Graph 1. Frequency distribution according to publication date indicator

during festive periods, such as the Thanksgiving (26/11/20) or Christmas holidays, he retained an important presence on the media agenda.

\section{Phase 2: Specific sample descriptors}

To enable deeper analysis of the media dissemination of the discourse on the delegitimization of the results championed by Trump, a specific sample $\left(n_{2}=2,222\right)$ was obtained by a thematic categorization of the general sample to identify messages related exclusively to the electoral process. These publications were analyzed using different indicators to measure the dissemination of tweets and their ability to generate a conversation with users (1), specific topics about the electoral process (2), and discourse frames based on coding keywords (3).

\section{Interactivity indicators}

The analysis of the theme variable enables the determination of the impact that these publications referring to Donald Trump had on the global conversation on Twitter and thus the importance that digital users attached to the debate on electoral fraud driven by the Republican candidate. The monitoring confirmed that these tweets generated a high level of interactivity, in terms of both retweets as well as likes or replies.

Table 4. Metric contingency and viralization capacity on Twitter depending on the communication medium

\begin{tabular}{|c|c|c|c|c|c|c|c|c|}
\hline & \multicolumn{8}{|c|}{ Medium } \\
\hline & $A B C$ & $A P$ & CBS News & CNN & Fox News & NBC News & Reuters & Total \\
\hline Followers & $16.6 \mathrm{M}$ & $15.1 \mathrm{M}$ & $8.1 \mathrm{M}$ & $53.3 \mathrm{M}$ & $20.1 \mathrm{M}$ & $8.4 \mathrm{M}$ & $23.3 \mathrm{M}$ & $144.9 \mathrm{M}$ \\
\hline Tweets (total) & 472 & 105 & 493 & 311 & 132 & 320 & 389 & 2,222 \\
\hline Replies (average) & 221 & 466 & 259 & 668 & 1,114 & 215 & 153 & 344 \\
\hline Retweets (average) & 301 & 2,473 & 254 & 755 & 633 & 483 & 304 & 503 \\
\hline Likes (average) & 1,279 & 6,574 & 975 & 3,547 & 3,289 & 1,234 & 731 & 1,796 \\
\hline Viralization & 1,881 & 11,520 & 1,483 & 5,057 & 4,555 & 2,200 & 1,339 & 2,803 \\
\hline Debate ability & 221 & 466 & 259 & 668 & 1,114 & 215 & 153 & 344 \\
\hline
\end{tabular}

To determine the capacity for viralization and influence of the tweets, a previously verified formula was chosen (Carrasco-Polaino; Villar-Cirujano; Tejedor-Fuentes, 2018), which assigns twice the value to retweets compared with likes and divides them by the total number of tweets. In this regard, the data (Table 4) revealed greater participation of the community of followers of the Associated Press $(11,520), \operatorname{CNN}(5,057)$, and Fox News $(4,555)$ accounts. On the basis of these results, it is observed that the leading role of the AP agency results in a thread of tweets (Image 1) related to the proclamation of Biden as the winner of the election, reaching significant virality rates on the network and producing more than 387,000 likes, 175,000 retweets, and 15,000 replies. 
CNN@@CNN.8 nov. 2020

First lady Melania Trump is among those telling President Trump to accept the election loss cnn.it/2leJqfB

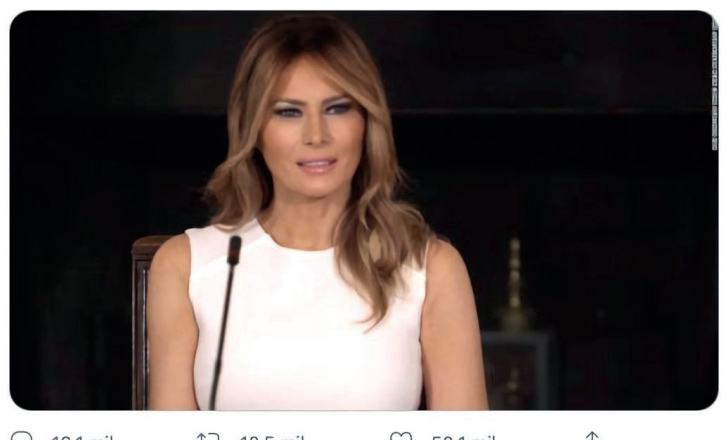

$\bigcirc 16,1 \mathrm{mil}$

†】 $10,5 \mathrm{mil}$

O $50,1 \mathrm{mil}$

$\uparrow$

Image 2. CNN tweet from the first lady advising Trump to accept his defeat. https://twitter.com/CNN/status/1325495559877177344
Fox News @FoxNews.7 nov. 2020

Fox News projects Biden to defeat Trump, become 46th president after winning Nevada, Pennsylvania fxn.ws/2JLCw7c

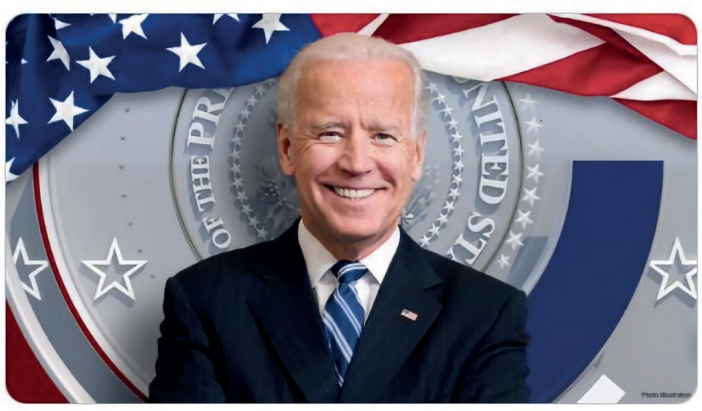

Q $6,7 \mathrm{mil}$

ใ】 $16,5 \mathrm{mil}$

O 49,3 mil

Image 3. Fox News tweet proclaiming Biden's victory over Trump https://twitter.com/FoxNews/status/1325117280670388226

The results for the liberal chain $C N N$ should be interpreted considering that its number of followers (53.3 million) is six times higher than that of other networks such as CBS or NBC. However, the case of Fox News is different since the high viralization of its publications $(4,555)$ is combined with a great capacity to generate replies $(1,114)$, being almost four times the average value (344). One of the possible causes could be related to the confrontational attitude of Trump and his followers toward this conservative chain after its recognition of Biden's victory.

At a global level, the metrics confirm the high activity of digital audiences in following the electoral process, with an average of 504 retweets, 1,796 likes, and 344 replies for each message analyzed. As a consequence of the political conflict, the participation and interaction of the public with the information disseminated by the media increased. In addition, the data confirm that, in this type of massive conversation, the capacity for viralization or to generate debate depends on not only the number of followers (Cha et al., 2010) but also other factors such as transmedia consumption (Rost; Bernardi; Bergero, 2016). This is reflected, for example, in the fact that the data from the international agency Reuters (with 23.3 million followers) are notably lower than those for the US television networks NBC News (8.4) or CBS News (8.1), with almost one-third of the followers.

\section{Thematic indicators and categorization of content and bias}

From a first reading of all the tweets published about the electoral process and considering the most often repeated thematic topics, as well as the presence of keywords, a catalog of specific topics related to the vote counting, the election, and the constitutional procedure was drawn up for the US presidential election. These data (Table 5) reveal many messages related to the electoral process, such as the election and the certification of votes (28.2\%), as well as legal appeals $(13.7 \%)$ and the transfer of power (11.7\%). Meanwhile, the positioning of political leaders $(11.1 \%)$, the riots $(7.4 \%)$, and the confrontation between the media and Trump (1.9\%) took a second place. The thematic analysis of the specific sample thus revealed that the media addressed the attempts to delegitimize the election results by disseminating verified information based on data from the electoral process. Within this dynamic, they avoid reproducing messages on the subject of conspiracy and electoral fraud that could increase uncertainty among citizens..

On the other hand, crossing the variables of specific theme and communication medium reveals the importance given by each media group to specific issues related to the electoral process. Although messages related to the vote counting, the election, and the certification of its results received the highest coverage from all the analyzed media, the focus on this matter was much higher for the CBS (38.7\%) and NBC (33.4\%) networks.

One of the aspects for which the greatest variation was detected is the process of the transfer of power between the Trump and Biden teams. It is striking that the liberal channel CNN (17.7\%) showed the greatest interest in this, while the conservative Fox News $(0.8 \%)$ practically ignored the issue. In this regard, one can observe that differences appear between the media with more disparate ideologies, possibly indicating the degree of interest of their audiences in the transfer of power between the administrations.

In addition, it was also found that both channels showed the greatest interest in the conflict between Donald Trump and the media. In this regard, it was observed that, after recognizing the triumph of Joe Biden, the conservative Fox News (5.3\%) joined the liberal CNN (4.5\%) in its confrontation with the Republican magnate, compared with other media outlets that ignored this confrontation.

The figures on the importance given to other aspects such as the positioning of political leaders, the riots, or the runoff election in Georgia reveal that the US media exhibited great variety in the composition of the thematic agenda. One 
Table 5. Indicator of specific topics depending on the communication medium

\begin{tabular}{|c|c|c|c|c|c|c|c|c|c|}
\hline \multirow[b]{2}{*}{ Specific theme } & \multicolumn{9}{|c|}{ Medium } \\
\hline & & $\begin{array}{c}A B C \\
\text { News }\end{array}$ & $A P$ & $\begin{array}{l}\text { CBS } \\
\text { News }\end{array}$ & CNN & Fox News & $\begin{array}{l}\text { NBC } \\
\text { News }\end{array}$ & Reuters & Total \\
\hline \multirow{2}{*}{ The election } & Count & 91 & 21 & 191 & 93 & 31 & 107 & 93 & 627 \\
\hline & $\%$ within medium & $19.3 \%$ & $20.0 \%$ & $38.7 \%$ & $29.9 \%$ & $23.5 \%$ & $33.4 \%$ & $23.9 \%$ & $28.2 \%$ \\
\hline \multirow{2}{*}{$\begin{array}{l}\text { Legal or } \\
\text { administrative } \\
\text { appeals }\end{array}$} & Count & 86 & 17 & 61 & 44 & 17 & 25 & 54 & 304 \\
\hline & $\%$ within medium & $18.2 \%$ & $16.2 \%$ & $12.4 \%$ & $14.1 \%$ & $12.9 \%$ & $7.8 \%$ & $13.9 \%$ & $13.7 \%$ \\
\hline \multirow{2}{*}{ Electoral College } & Count & 8 & 4 & 4 & 17 & 4 & 18 & 9 & 64 \\
\hline & $\%$ within medium & $1.7 \%$ & $3.8 \%$ & $0.8 \%$ & $5.5 \%$ & $3.0 \%$ & $5.6 \%$ & $2.3 \%$ & $2.9 \%$ \\
\hline \multirow{2}{*}{ Transfer of power } & Count & 57 & 16 & 59 & 55 & 1 & 28 & 45 & 261 \\
\hline & $\%$ within medium & $12.1 \%$ & $15.2 \%$ & $12.0 \%$ & $17.7 \%$ & $0.8 \%$ & $8.8 \%$ & $11.6 \%$ & $11.7 \%$ \\
\hline \multirow{2}{*}{$\begin{array}{l}\text { Positioning of parties } \\
\text { and politicians }\end{array}$} & Count & 65 & 8 & 28 & 26 & 26 & 24 & 70 & 247 \\
\hline & $\%$ within medium & $13.8 \%$ & $7.6 \%$ & $5.7 \%$ & $8.4 \%$ & $19.7 \%$ & $7.5 \%$ & $18.0 \%$ & $11.1 \%$ \\
\hline \multirow{2}{*}{$\begin{array}{l}\text { Riots or demonstra- } \\
\text { tions }\end{array}$} & Count & 16 & 14 & 39 & 15 & 4 & 41 & 36 & 165 \\
\hline & $\%$ within medium & $3.4 \%$ & $13.3 \%$ & $7.9 \%$ & $4.8 \%$ & $3.0 \%$ & $12.8 \%$ & $9.3 \%$ & $7.4 \%$ \\
\hline \multirow{2}{*}{$\begin{array}{l}\text { Confrontation } \\
\text { between the media } \\
\text { and Trump }\end{array}$} & Count & 10 & 1 & 2 & 14 & 7 & 1 & 7 & 42 \\
\hline & $\%$ within medium & $2.1 \%$ & $1.0 \%$ & $0.4 \%$ & $4.5 \%$ & $5.3 \%$ & $0.3 \%$ & $1.8 \%$ & $1.9 \%$ \\
\hline \multirow{2}{*}{$\begin{array}{l}\text { Runoff election in } \\
\text { Georgia }\end{array}$} & Count & 18 & 2 & 30 & 27 & 6 & 8 & 27 & 118 \\
\hline & $\%$ within medium & $3.8 \%$ & $1.9 \%$ & $6.1 \%$ & $8.7 \%$ & $4.5 \%$ & $2.5 \%$ & $6.9 \%$ & $5.3 \%$ \\
\hline \multirow{2}{*}{ Others } & Count & 121 & 22 & 79 & 20 & 36 & 68 & 48 & 394 \\
\hline & $\%$ within medium & $25.6 \%$ & $21.0 \%$ & $16.0 \%$ & $6.4 \%$ & $27.3 \%$ & $21.3 \%$ & $12.3 \%$ & $17.7 \%$ \\
\hline \multirow[t]{2}{*}{ Total } & Count & 472 & 105 & 493 & 311 & 132 & 320 & 389 & 2,222 \\
\hline & $\%$ within medium & $100 \%$ & $100 \%$ & $100 \%$ & $100 \%$ & $100 \%$ & $100 \%$ & $100 \%$ & $100 \%$ \\
\hline
\end{tabular}

\begin{tabular}{|l|c|c|c|}
\hline & Chi-square tests & df & Asymptotic significance (bilateral) \\
\hline Pearson chi squared & $299,687^{\mathrm{a}}$ & 48 & 0 \\
\hline Likelihood ratio & 314,303 & 48 & 0 \\
\hline Linear to linear association & 1.68 & 1 & 2,222 \\
\hline N of valid cases & & 0.195 \\
\hline a Four entries (6.3\%) are expected to have a count less than 5. The minimum expected count is 1.98. \\
\hline
\end{tabular}

example of this is that $A B C(25.6 \%)$ reported four times more than $C N N(6.4 \%)$ on the Senate election in Georgia that would allow the Democratic Party to take control of the US Senate.

To delve into the mechanisms deployed by the media in the face of the attempt to delegitimize the electoral process, we studied the angle adopted by the journalistic activity. Thus, the monitoring of the published tweets (Fig. 5) revealed a commitment by the media to inform and include data that counteract Trump's discourse on conspiracy and electoral fraud. This translates into the dissemination of a vast majority of tweets with informative content (80.4\%), that is, aimed at relating current events of general interest (Casals, 2005). In contrast, very few (11.2\%) showed an interpretive character or described the relationship of the news with its context, or were opinion pieces (8.4\%), that is, messages in which the journalist takes sides or tries to convince the reader (Núñez-Ladevèze, 1995). The results indicate that these media are clearly committed to addressing the discourse on electoral fraud promoted by Trump by presenting an objective and truthful account of the events, relying on verifiable data from reliable sources (Martínez-Albertos, 1989).

If we disaggregate the informational content data by crossing them with the communication medium variable, the percentages still reflect a strong commitment to information, albeit with different nuances. On the one hand, it should be noted that, for $C N N$, the number of publications describing events reduced to $68.2 \%$, since it was also committed to interpretation (15.8\%) and opinion (16.1\%). In contrast, the conservative chain Fox News opted almost entirely for the dissemination of informative tweets (93.9\%), without positioning itself in favor of or against Trump's position. As can be seen, the media outlets whose audiences have less similar ideology show notable differences. Thus, the chain closest to 


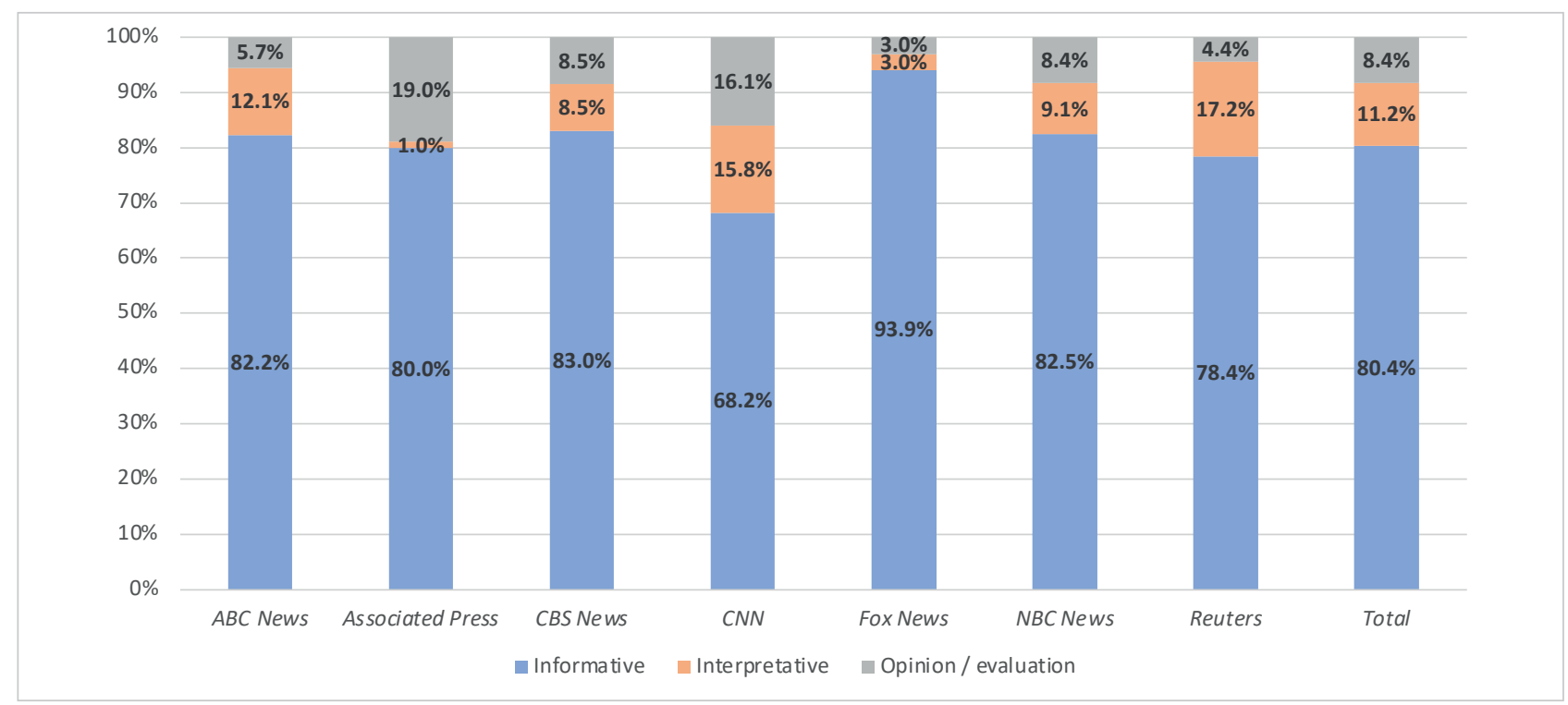

Graph 2. Categorization of informative content by communication medium

the Democrats decides to take sides against Trump's discourse and provide key information so that its audience can interpret the facts. In contrast, the most conservative media, subject to criticism from Republicans for recognizing Biden's victory, defended themselves by opting for an almost exclusively informative account of the events.

Another important aspect when assessing journalistic quality is the source of the information disseminated by the media. This has led to the primary debate in journalism about the reproduction of partisan versions (Dader, 2014) or the construction of the news according to one's own version of the story (Epstein, 1975). In the case of the sample studied, most of the messages related to the electoral process (Fig. 6) are based on information produced by the media itself $(42.3 \%)$ and on statements by prestigious political scientists, sociologists, or jurists $(18 \%)$. In contrast, and to a lesser extent, their publications focus on statements by Donald Trump (16.5\%), Joe Biden (6.3\%), or other political leaders (16.9\%). As can be seen, the main tendency is to produce information based on journalistic or expert criteria (60.3\%) rather than quotations from authorities (39.7\%). In this case, we observe that the media reclaim their role as producers of information and are committed to objectivity, presenting their own account of the events while ignoring sources linked to the ruling power.

Breaking down the data for the different media studied reveals that the strategy of giving priority to journalistic information about the electoral process over so-called declarative journalism (Martínez-Nicolás; Humanes, 2012; Munive, 2016 ) is disrupted especially in the case of Fox News, whose main source is the Republican leader (43.2\%) compared with self-produced tweets (22\%). In this case, it could be considered that, despite the rejection of the discourse of electoral fraud, this conservative channel continues to focus on the Republican leader, responding to an audience profile close to Trump. Faced with this, different strategies are observed in the other communication media to stop the social

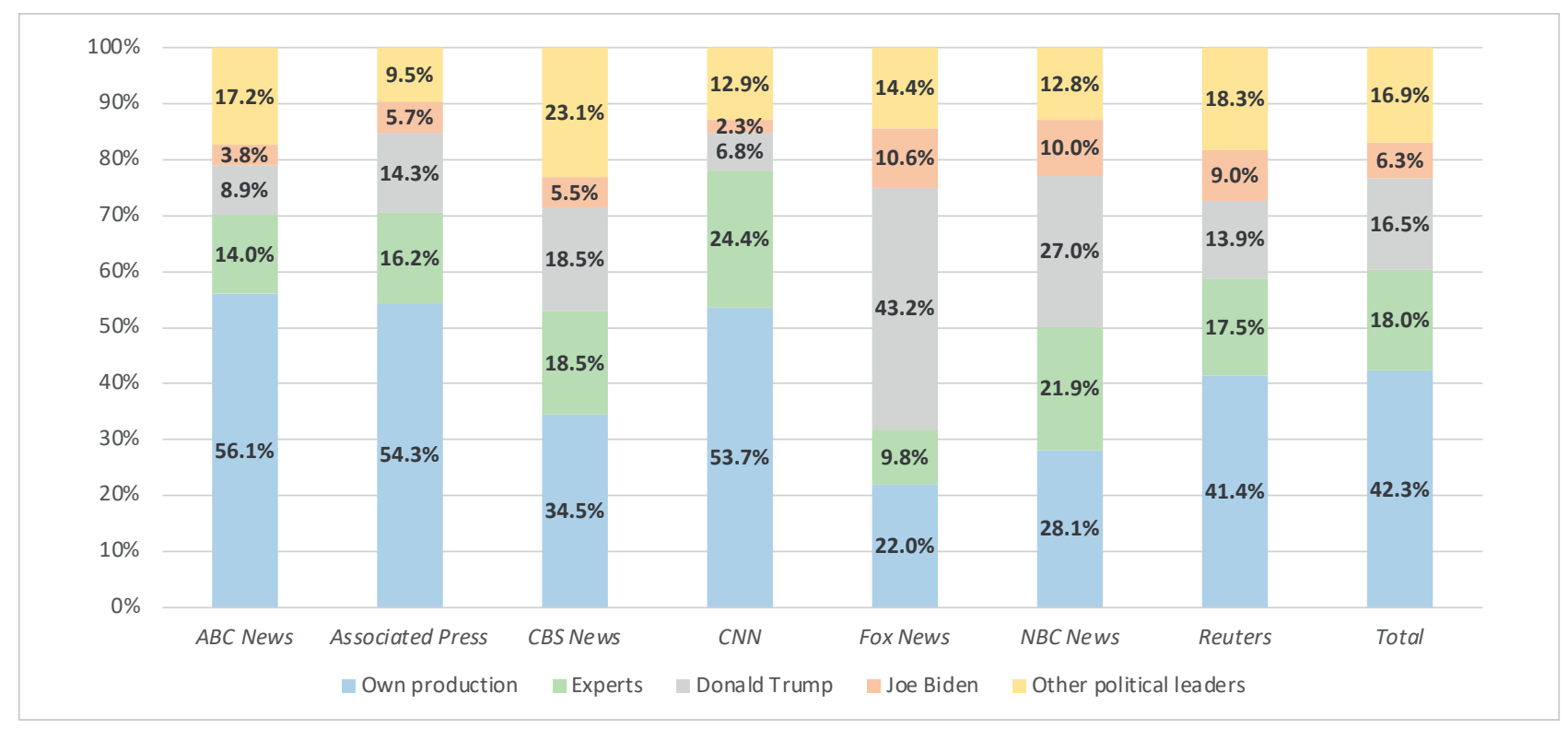

Graph 3. Source of the information depending on the communication medium 


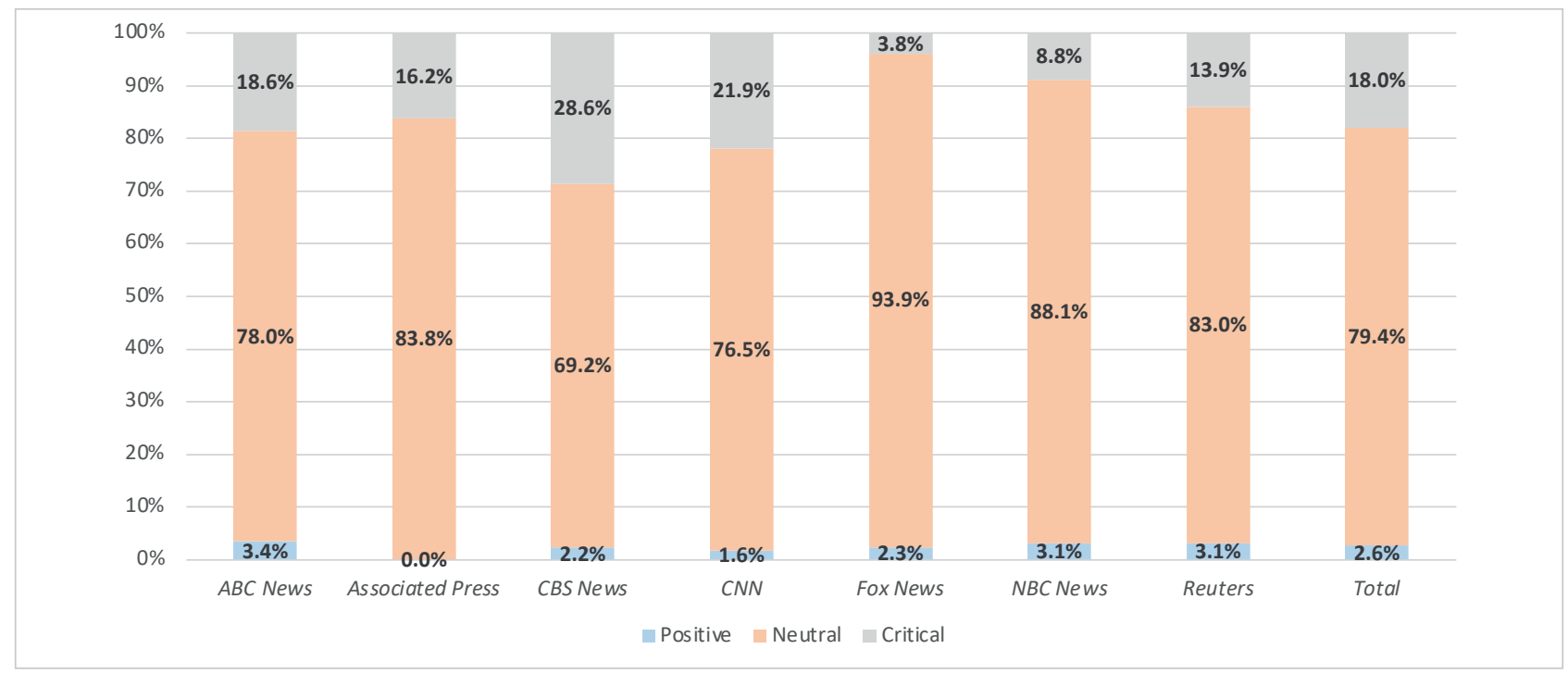

Graph 4. Bias coding of the message depending on the communication medium

destabilization generated by Trumpist disinformation. Thus, $C N N(6.8 \%)$ and $A B C$ (8.9\%) directly ignore Donald Trump's discourse, while CBS (23.1\%) and Reuters $(18.3 \%)$ are committed to broadening the focus and incorporating a spectrum of statements from other political leaders (Amado, 2014). However, it is striking that the media do not rely on statements by the Democratic candidate Joe Biden to address Trump's conspiracy theories and fallacy.

This analysis of the attitudes of the US mass media in their treatment of the election leads to the contemplation of political bias as a category to define the tendency or inclination of a given media outlet towards a particular political cause, with the aim of orienting viewers towards a concrete ideological position (Gunter, 1997). Considering the character limit on tweets, to analyze the possible bias of the news media regarding Donald Trump, we focus on the use of language or lexical selection (Lee; Solomon, 1990; Fernández-García, 2005; Verdú, 2009) as indicators of the tone of the message.

In line with the previous indicators, it is observed (Fig. 7) that the US media mainly adopt a neutral tone, free of negative or positive framing, to report on the electoral process (79.4\%). However, there are also messages with a negative bias referring to Trump (18\%), compared with the practical absence of tweets in support of his narrative (2.6\%). The data reveal that, in this context of social instability marked by misinformation, these media chosen by Twitter as official sources of information about the election exhibit a commitment to objectivity, truthfulness, and fact checking.

Crossing the bias with the communication medium variable, the data reflect that the conservative chain Fox News is most committed to neutrality (93.9\%), barely publishing messages with a critical bias against the Republican candidate. In contrast, CBS News (28.6\%) and CNN (21.9\%) do present a tendency to reject Trump's delegitimization discourse. This finding could indicate that the tendency of the conservative media to produce neutral messages, free from frames that favor or go against Trump's policy, is a protective measure against Republican attacks, while other media with liberal ideology use mechanisms based on language and keywords to counter the candidate's story.

Delving into these data and starting from the combination of bias and dissemination variables for each medium (Table 6) confirms the greater participation and interactivity of the audience in the face of information of a neutral nature and thus based on factual information and verified data. The figures indicate that these publications achieve a higher viralization rate $(2,951)$ compared with those that incorporate negative frames or exhibit rejection of Trump $(2,275)$, or those with a positive tone, in favor of the leader $(1,911)$. However, the latter generate a greater debate on the social network (402) compared with posts with a neutral tone (367) and almost twice as much as negative ones (232). This online dynamic of the media reinforces the commitment to information as a formula to consolidate the verification and veracity of the messages published on Twitter. Likewise, it responds in some way to the animosity that part of the US electorate has expressed in public opinion polls (Pew Research, 2021; Jones, 2021) against President Trump's policy of destabilization and disinformation. 
However, all these results must be analyzed in the light of the sample studied, which comprises prestigious media with mixed audiences (except Fox News and CNN) and framed in the Anglo-Saxon tradition in which an explicit presence of the editorial line is not part of the journalistic strategy (Martínez-Albertos, 1984). In any case, this possible tendency of conventional media to present a story based on facts hints at a commitment to democratic health at a time of institutional crisis and disaffection among citizens.

\section{Indicators of discourse and keyword rhetoric}

The exploration of the data related to the first 100 keywords with the highest frequency in the published tweets $(2,222)$, as well as their combinations, indicates that the terms most widely used by the media in their tweets are directly related to the electoral process. All of this supports the results obtained in the thematic indicators section, since 41 of the 100 most often repeated words appear to be linked to the presidential election (Trump, president, election, Biden, campaign, or transition), the count (vote, election, ballot paper, or count), the verification of the results (Electoral College or certification), and the most tightly disputed states (Georgia, Pennsylvania, Michigan, Wisconsin, or Arizona).

All this is configured as the main discursive axis of the publications, in addition to a significant frequency of other terms related to the general political context (Republican, Congress, Capitol, Senate, GOP, Democrat, or Washington). In this sense, the results suggest that the media construct their messages from a majority of technical words that refer directly to the electoral process, while avoiding ideological bias.

However, we also identify another series of words with semantic loading that allow the identification of the linguistic mechanisms used by the media when supporting or fighting the dialog of delegitimization of the election promoted by Donald Trump and his followers on Twitter. These are linguistic frames that identify the story of the so-called conspiracy theory (claim, fraud, cancel, or challenge).

However, and thanks to the study of the linguistic combinations allowed by the AntConc software, it is observed that the media tried to counter Trump's discourse, especially during the post-election period. This is reflected, for example, in the fact that the word complaint appears 236 times, in most cases accompanied by the terms false (40), baseless (25), or unsubstantiated (12). All this is completed with words related to the discourse on the legal process against Trump (court, lawsuit, Supreme, attorney or judge). However, these terms are reinforced with informational data and messages referring to the decision of legal bodies to reject Trump's arguments about electoral fraud.

In line with the verification strategies of the mass media, another series of language frames is frequently used to confront false statements about the illegality of the electoral results.

The metrics also indicate that the media call Joe Biden the President-Elect numerous times (310), linking him to the term to win on a regular basis (71 out of the 130 times on which it appears). In this way, the media ratify the acceptance of the Democratic candidate as the winner of the election and justify his legitimacy in the face of public opinion. On the contrary, it is found that Trump is associated with to lose (on 55 of 104 occasions) and loss (on 40 of the 66 times on which this word is used).

The global and specific data provided by the lemmatized semantic analysis reinforce the theory that the mass media under study assume the role of arbitrators in the electoral contest. To this end, they deploy a series of discursive strategies, supported by the use of keywords, that help to build an informative story about the electoral process, stop Trump's theory of electoral fraud, and vouch for the results, thus strengthening the commitment of journalism to objectivity, truthfulness, and transparency.

\section{Conclusions}

The most recent US presidential election paints a scenario dominated by the denunciation of electoral fraud and conspiracy by Donald Trump on social networks, thus generating a climate of confusion and public distrust in politics, as confirmed by polls of the electorate (Pérez-Curiel; Domínguez-García; Jiménez-Marín, 2021). The maximum levels of polarization and conflict coincided with the assault on the Capitol, highlighting the instability of the establishment.

In this regard, the current study confirms a reactivation on Twitter of certain conventional US media, which converge with a common dynamic to report on the electoral process and respond somehow to the rhetoric of populism, delegitimization, and disinformation promoted by Trump (Pérez-Curiel; Rivas-de-Roca; García-Gordillo, 2021). In comparison with the 2016 election, which exhibited lower ranges of online activity from the gene-
The neutrality of the media in the face of information related to Trump and the election process is a constant in the messages posted on Twitter. As a general rule, they avoid partisan bias and polarization 
ralist media and a strategy of open confrontation with the Republican candidate (Rúas-Araújo; Mazaira; Rodríguez-Vázquez, 2018; Pérez-Curiel; Limón-Naharro, 2020), the media activity during the 2020 election was dedicated to providing information on the election, the transfer of power, and legal appeals, while avoiding interpretation and opinion. Even the media closest to the president became involved in a process in which news journalism prevailed over journalism from sources. The neutrality of the media in the face of information related to Trump and the election process is a constant in the messages posted on Twitter. As a general rule, they avoid partisan bias and polarization, factors inherent to situations of political and health crises (Ali; Gatiti, 2020).

After a stage marked by an explosion of social networks and the prominence of new voices that became opinion leaders (Pérez-Curiel; Limón-Naharro, 2019), fueling the belief among digital users that they can be informed through their peers without having to resort to professional media (Gil de Zúñiga; Weeks; Ardèvol-Abreu, 2017), the recovery of the authority of journalism as a way of guaranteeing the credibility of facts in the face of disinformation must be a primary objective (Carlson, 2017).

Identifying the causes explaining why, in the 2020 election, certain media with positions close to and contrary to Donald Trump's decided to report on Twitter about the results of the electoral process and prevent the dissemination of messages related to the fraud discourse of the President, why they present an account of the events based on data, or why they use expert sources as a verification strategy requires a retrospective of the 2016 US election (Rúas-Araújo; Mazaira; Rodríguez-Vázquez, 2018). On the one hand, direct attacks from the mainstream media on the fallacy and propaganda of the leader, alerting the public to the consequences of extreme populism (Pérez-Curiel; Rivas-de-Roca; García-GordiIlo, 2021), could not prevent Trump's victory in the election, which was endorsed by a large majority of voters. On the other hand, throughout the legislature, the media witnessed his policy of rejecting the establishment, Europeanism (Mammone, 2009), and immigration (Wodak, 2015), as well as a rhetoric of hoaxes created around the pandemic (Pérez-Curiel; Velasco-Molpeceres, 2020). Finally, the chance to recover an audience hitherto little interested in political matters (Lee; Xenos, 2019) and which shows signs of confusion caused by misinformation on social networks (Gil de Zúñiga; Huber; Strauß, 2018) and exhibits an increase in doubt about the demonstrations promoted by Trump on Twitter constitutes another possible reason encouraging the provision of high-quality information by the media.

The exploration of the results confirms the shared action of the networks and news agencies on Twitter to disseminate information about the electoral process that counteracts the theory of electoral fraud and delegitimization of Trump (RQ1). Even networks such as Fox News, which have traditionally supported conservative positions and have shown affinity with the leader's discourse, constructed a verified account of the events, thereby facing criticism from the Republican leader.

Faced with the dynamics of the projection of Trump's messages on the front pages and the reproduction of the fallacy in their headlines, typical of previous elections, a trend that prioritizes informing about the facts and data journalism rather than interpretation and opinion is observed. Likewise, declarative journalism (Munive, 2016) favors the selection of expert sources that support the reliability of the process and thereby the constitutional guarantee provided by institutions. In this sense, the generalist media policy observed on Twitter is characterized by the dissemination of high-quality information, free of bias, using context frames and creating an informative account that confirms the truth for the audience.

Somehow, the media thereby regain their primacy as producers of information and monitor the influence of sources linked to power. These are indicators of journalistic quality (RQ2), aimed at promoting truthfulness and credibility that, in the short term, can reverse the climate of disinformation to which citizens are exposed.

To assess the extent to which media action was able to contribute to spreading or deactivating Trump's conspiracy theory (RQ3), it is essential to analyze the position of neutrality that prevailed throughout the narrative on the electoral process. In this regard, the primacy of the political bias inherent to the media is questioned, in turn reversing the theory of audience confirmation bias (Pennycook; Rand, 2018; Wason, 1960), as a formula to ignore arguments and evidence that challenge prior beliefs (Salaverría et al., 2020). The results of this study reveal, in crisis situations, the interest of users in news disseminated by professional media (Gil de Zúñiga; Weeks; Ardèvol-Abreu, 2017), which enjoys higher viralization rates than other material with a negative or positive tone on the discourse of delegitimization of the election. As found in other work (Casero-Ripollés, 2020), the public, when faced with a risky information context, opts for information sources with a long history and higher levels of consumption.

In short, during a health crisis with social disruption such as that experienced in the USA, the media implemented a protocol for the production of their own content and acted as disinformation deactivators (Naderi; Hirst, 2018).

With respect to previous investigations, this study proposes an advance in the aim of journalism to act as an alternative to challenge the uncontrolled production of disinformation. In an electoral context marked by attempts to delegitimize the US president, the commitment of the conventional media to truthfulness, fact checking, and high quality stands out. Proven 
facts such as the viralization rates achieved by news messages, typical of Anglo-Saxon journalism, are indicators of support from citizens for the work of the media to inform against the contamination of the political discourse on the election.

In any case, considering the limitations of this research approach, such as the Twitter sample selection that proposes media with a mostly generalist profile as official sources of information on the election, these findings cannot be extrapolated to other media with marked party affinity. Therefore, they must be interpreted in the light of the exceptional political and communicative context centered on the 2020 US presidential election.

Future lines of research could analyze the role of journalism in the treatment of electoral information, considering the breadth of the ecosystem of social networks that overcomes the barriers of traditional media outlets, notwithstanding the process of media hybridization (Chadwick, 2019). From another angle, determining the extent to which citizens value media information to combat the cacophony of voices active on social networks or apply media education strategies that position them as participatory and critical actors represent new approaches to address the risks of a single discourse with as yet unpredictable effects on democracy.

\section{References}

Ali, Muhammad-Yousuf; Gatiti, Peter (2020). "The Covid-19 (coronavirus) pandemic: reflections on the roles of librarians and information professionals". Health information \& libraries journal, v. 37, n. 2, pp. 158-162.

https://doi.org/10.1111/hir.12307

Alonso-Muñoz, Laura; Marcos-García, Silvia; Casero-Ripollés, Andreu (2016). "Political leaders in (inter)action. Twitter as a strategic communication tool in electoral campaigns". Trípodos, n. 39, pp. 71-90.

http://www.tripodos.com/index.php/Facultat_Comunicacio_Blanquerna/article/view/381

Amado, Adriana (2014). "Los hechos y los dichos en las noticias: la polifonía del discurso periodístico". Romanica olomucensia, v. 26, n. 2, pp. 143-156.

https://doi.org/10.5507/ro.2014.017

Anthony, Laurence (2021). AntConc (versión 3.5.9) [software informático]. Tokio: Waseda University. https://www.laurenceanthony.net/software/antconc

Bakker, Ryan; Jolly, Seth; Polk, Jonathan (2020). “Multidimensional incongruence, political disaffection, and support for anti-establishment parties". Journal of European public policy, v. 27, n. 2, pp. 292-309.

https://doi.org/10.1080/13501763.2019.1701534

Balz, Dan; Clement, Scott; Guskin, Emily (2021). "Biden wins wide approval for handling of transition, but persistent GOP skepticism on issues will cloud the opening of his presidency, Post-ABC poll finds". The Washington Post, 17 January. https://www.washingtonpost.com/politics/poll-biden-trump-republicans/2021/01/16/5e41c9ba-575b-11eb-a08bf1381ef3d207_story.html

Bennett, W. Lance; Livingston, Steven (2018). "The disinformation order: Disruptive communication and the decline of democratic institutions". European journal of communication, v. 33, n. 2, pp. 122-139.

https://doi.org/10.1177/0267323118760317

Bennett, W. Lance; Pfetsch, Barbara (2018). "Rethinking political communication in a time of disrupted public spheres". Journal of communication, v. 68 n. 2, pp. 243-253.

https://doi.org/10.1093/joc/jqx017

Bernicot, Josie; Goumi, Antonine; Bert-Erboul, Alain; Volckaert-Legrier, Olga (2014). “How do skilled and less-skilled spellers write text messages? A longitudinal study". Journal of computer assisted learning, v. 30, n. 6, pp. 559-576.

https://doi.org/10.1111/jcal.12064

Caldera-Serrano, Jorge; Nuño-Moral, María-Victoria; Zapico-Alonso, Felipe (2004). "Las agencias internacionales de noticias como fuente de información audiovisual". Scire, v. 10, n. 2, pp. 137-146.

https://www.ibersid.eu/ojs/index.php/scire/article/view/1500

Carlson, Matt (2017). Journalistic authority: legitimating news in the digital era. Columbia University Press. ISBN: 0231174454

Carrasco-Polaino, Rafael; Villar-Cirujano, Ernesto; Tejedor-Fuentes, Laura (2018). "Twitter como herramienta de comunicación política en el contexto del referéndum independentista catalán: asociaciones ciudadanas frente a instituciones públicas". Icono 14, v. 16, n. 1, pp. 64-85.

https://doi.org/10.7195/ri14.v16i1.1134 
Casals, María-Jesús (2005). Periodismo y sentido de la realidad. Teoría y análisis de la narrativa periodística. Madrid: Fragua. ISBN: 8470741705

Casero-Ripollés, Andreu (2018). "Research on political information and social media: Key points and challenges for the future". El profesional de la información, v. 27, n. 5, pp. 964-974.

https://doi.org/10.3145/epi.2018.sep.01

Casero-Ripollés, Andreu (2020a). "Impact of Covid-19 on the media system. Communicative and democratic consequences of news consumption during the outbreak". El profesional de la información, v. 29, n. 2.

https://doi.org/10.3145/epi.2020.mar.23

Casero-Ripollés, Andreu (2020b). "Influence of media on the political conversation on Twitter: Activity, popularity, and authority in the digital debate in Spain". Icono14. Revista científica de comunicación y tecnologías emergentes, v. 18, n. 1, pp. 33-57.

https://doi.org/10.7195/ri14.v18i1.1527

Cha, Meeyoung; Haddadi, Hamed; Benevenuto, Fabrício; Gummadi, Krishna P. (2010). “Measuring user influence in Twitter: The million follower fallacy". In: Proceedings of the fourth international AAAl conference on weblogs and social media. AAAI Press, pp. 10-17.

http://citeseerx.ist.psu.edu/viewdoc/summary?doi=10.1.1.167.192

Chadwick, Andrew (2017). The hybrid media system: politics and power. Oxford: Oxford University Press. ISBN: 9780 190696733

CNN (2020a). "Exit polls: national results". CNN politics.

https://edition.cnn.com/election/2020/exit-polls/president/national-results

CNN (2020b). "Presidential results". CNN politics.

https://edition.cnn.com/election/2020/results/president

Congosto, Mariluz; Basanta-Val, Pablo; Sánchez-Fernández, Luis (2017). “T-Hoarder: A framework to process Twitter data streams". Journal of network and computer applications, n. 83, pp. 28-39.

https://doi.org/10.1016/j.jnca.2017.01.029

Crilley, Rhys; Gillespie, Marie (2019). "What to do about social media? Politics, populism and journalism". Journalism, v. 20 , n. 1 , pp. $173-176$.

https://doi.org/10.1177/1464884918807344

Dader, José-Luis (2014). “El periodista, entre el poder". Revista latina de comunicación social, n. 69, pp. 637-660. https://doi.org/10.4185/RLCS-2014-1028

D’Heer, Evelien; Verdegem, Pieter (2015). "What social media data mean for audience studies: a multidimensional investigation of Twitter use during a current affairs TV programme". Information, communication and society, v. 18, n. 2 , pp. 221-234.

https://doi.org/10.1080/1369118X.2014.952318

De-la-Torre, Carlos (2018). “Leyendo a Donald Trump desde América Latina”. Revista SAAP: Sociedad Argentina de Análisis Político, v. 12, n. 1, pp. 179-194.

https://revista.saap.org.ar/contenido/revista-saap-v12-n1/SAAP_12_1-De_La_Torre.pdf

Duque, Eladio (2014). “Análisis de contenido mediante análisis de palabras clave: la representación de los participantes en los discursos de Esperanza Aguirre”. Mediaciones sociales, n. 13, pp. 39-73.

https://doi.org/10.5209/rev_MESO.2014.n13.49432

Dutta-Bergman, Mohan J. (2004). "Complementarity in consumption of news types across traditional and new media". Journal of broadcasting \& electronic media, v. 48, n. 1, pp. 41-60.

https://doi.org/10.1207/s15506878jobem4801_3

Enli, Gunn (2017). "Twitter as arena for the authentic out-sider: exploring the social media campaigns of Trump and Clinton in the 2016 US presidential election". European journal of communication, v. 32, n. 1, pp. 50-61.

https://doi.org/10.1177/0267323116682802

Epstein, Edward-Jay (1975). Between fact and fiction: the problem of journalism. New York. Vintage Books. ISBN: 0394713966

Esser, Frank; De-Vreese, Claes H.; Strömbäck, Jesper; Van-Aelst, Peter; Aalberg, Toril; Stanyer, James; Lengauer, Günther; Berganza, Rosa; Legnante, Guido; Papathanassopoulos, Stylianos; Salgado, Susana; Sheafer, Tamir; Reinemann, Carsten (2012). "Political information opportunities in Europe: A longitudinal and comparative study of thirteen television systems". The international journal of press/politics, v. 17, n. 3, pp. 247-274.

https://doi.org/10.1177/1940161212442956 
Fajardo-Trigueros, Clara; Rivas-de-Roca, Rubén (2020). “La acción de la UE en España ante la 'infodemia' de desinformación por el Covid-19". Revista de estilos de aprendizaje, v. 13, n. 26, pp. 19-32.

http://revistaestilosdeaprendizaje.com/article/view/2153

Fernández-García, Francisco (2005). Érase una vez: la narración informativa en televisión. Universidad de Jaén. ISBN: 8484392767

Flowerdew, John; Richardson, John E. (eds.) (2017). The Routledge handbook of critical discourse studies. Taylor \& Francis. ISBN: 1138826405

Fuentes-Rodríguez, Catalina (2020). Estrategias argumentativas y discurso político. Madrid: Arco Libros. ISBN: 97884 76359495

Gadde, Vijaya; Beykpour, Kayvon (2020). “Additional steps we're taking ahead of the 2020 US election". Twitter, 9 October.

https://blog.twitter.com/en_us/topics/company/2020/2020-election-changes.htm/

Gerbaudo, Paolo (2018). "Social media and populism: an elective affinity?". Media, culture \& society, v. 40, n. 5, pp. 745-753.

https://doi.org/10.1177/0163443718772192

Gil de Zúñiga, Homero; Huber, Brigitte; Strauß, Nadine (2018). "Social media and democracy". El profesional de la información, v. 27, n. 6, pp. 1172-1180.

https://doi.org/10.3145/epi.2018.nov.01

Gil de Zúñiga, Homero; Weeks, Brian; Ardèvol-Abreu, Alberto (2017). "Effects of the news-finds-me perception in communication: Social media use implications for news seeking and learning about politics". Journal of computer-mediated communication, v. 22, n. 3, pp. 105-123.

https://doi.org/10.1111/jcc4.12185

Gunter, Barrie (1997). Measuring bias on television. Luton: University of Luton. ISBN: 9781860205262

Habermas, Jürgen (2006). "Political communication in media society: Does democracy still enjoy an epistemic dimension? The impact of normative theory on empirical research". Communication theory, v. 16, n. 4, pp. 411-426.

https://doi.org/10.1111/j.1468-2885.2006.00280.x

Jones, Jeffrey M. (2021). "Last Trump job approval 34\%; Average is record-low 41\%". Gallup, 18 January. https://news.gallup.com/poll/328637/last-trump-job-approval-average-record-low.aspx

Kaiser, Brittany (2020). "I blew the whistle on Cambridge Analytica - four years later, Facebook still hasn't learnt its lesson". The independent.

Kovach, Bill; Rosenstiel, Tom (2007). The elements of journalism: what newspeople should know and the public should expect. New York: Three Rivers Press. ISBN: 9780307346704

Krippendorff, Klaus (2004). Content analysis. Sage. ISBN: 9780761915454

Lee, Martin A.; Solomon, Norman (1990). Unreliable sources: a guide to detecting bias in news media. New York: Lyle Stuart book. ISBN: 9780818405211

Lee, Sangwon; Xenos, Michael (2019). "Social distraction? Social media use and political knowledge in two US presidential elections". Computers in human behavior, v. 90, pp. 18-25.

https://doi.org/10.1016/j.chb.2018.08.006

Levitsky, Steven; Ziblatt, Daniel (2018). How democracies die. New York: Broadway Books. ISBN: 9781524762940

Lockwood, James; Mooney, Aidan (2018). "Computational thinking in secondary education: where does it fit? A systematic literary review". International journal of computer science education in schools, v. 2, n. 1.

https://eric.ed.gov/?id=ED581487

Mammone, Andrea (2009). "The eternal return? Faux populism and contemporarization of neo-Fascism across Britain, France and Italy". Journal of contemporary European studies, v. 17, n. 2, pp. 171-192. https://doi.org/10.1080/14782800903108635

Mancera-Rueda, Ana; Pano-Alamán, Ana (2014). "Las redes sociales como corpus de estudio para el análisis del discurso mediado por ordenador". Janus: estudios sobre el siglo de oro, Anexo 1, pp. 305-315.

http://hdl.handle.net/11441/60827

Manfredi-Sánchez, Juan-Luis; Amado-Suárez, Adriana; Waisbord, Silvio (2021). "Presidential Twitter in the face of Covid-19: between populism and pop politics". Comunicar, n. 66, pp. 83-94.

https://doi.org/10.3916/C66-2021-07 
Martínez-Albertos, José-Luis (1984). Curso general de redacción periodística. Barcelona: Maitre. ISBN: 8486153034

Martínez-Albertos, José-Luis (1989). El lenguaje periodístico. Madrid: Paraninfo. ISBN: 8428317283

Martínez-Nicolás, Manuel; Humanes, María-Luisa (2012). “Culturas profesionales del periodismo político en España. El discurso de los periodistas sobre la política y las funciones políticas de los medios". En: Casero-Ripollés, Andreu. Periodismo político en España: concepciones, tensiones y elecciones. Tenerife: Sociedad Latina de Comunicación Social, pp. 47-65. ISBN: 9788415698098

Mounk, Yascha (2018). The people vs. democracy. Why our freedom is in danger and how to save it. USA: Harvard University Press. ISBN: 9780674976825

Mudde, Cas (2016). “Europe's populist surge: A long time in the making”. Foreign affairs, v. 95, n. 6, pp. 25-30. https://www.researchgate.net/publication/309643775_Europe's_Populist_Surge_A_Long_Time_in_the_Making

Munive, Mario (2016). "Periodismo de declaraciones: Cuando la prensa renuncia a ser el lugar de los hechos". Conexión, n. 6, pp. 42-57.

https://revistas.pucp.edu.pe/index.php/conexion/article/view/16456

Naderi, Nona; Hirst, Graeme (2018). "Automated fact-checking of claims in argumentative parliamentary debates". In: Proceedings of the first workshop on fact extraction and verification, pp. 60-65.

https://doi.org/10.18653/v1/W18-5509

Neudert, Lisa-Marie; Marchal, Nahema (2019). Polarisation and the use of technology in political campaigns and communication. European Parliamentary Research Service Scientific Foresight Unit (STOA).

https://doi.org/10.2861/167110

Núñez-Ladevéze, Luis (1995). Introducción al periodismo escrito. Barcelona: Ariel. ISBN: 8434412640

Ott, Brian L. (2017). "The age of Twitter: Donald J. Trump and the politics of debasement". Critical studies in media communication, v. 34, n. 1, pp. 59-68.

https://doi.org/10.1080/15295036.2016.1266686

Panetta, Kasey (2017). "Gartner top strategic predictions for 2018 and beyond". Gartner. https://www.gartner.com/smarterwithgartner/gartner-top-strategic-predictions-for-2018-and-beyond

Palau-Sampio, Dolors; Gómez-Mompart, Josep-Lluís (2015). “Calidad y credibilidad, un binomio inexorable para el futuro de los medios". Periodística, n. 16, pp. 11-28.

https://raco.cat/index.php/Periodistica/article/view/321204

Pellegrini, Silvia; Múgica, María-Constanza (2006). “Valor agregado periodístico (VAP): la calidad periodística como factor productivo en un entorno medial complejo". Palabra clave, v. 9, n. 1.

https://www.redalyc.org/pdf/649/64900101.pdf

Pennycook, Gordon; Rand, David G. (2018). "Lazy, not biased: susceptibility to partisan fake news is better explained by lack of reasoning than by motivated reasoning". Cognition, v. 188, pp. 39-50.

https://doi.org/10.1016/j.cognition.2018.06.011

Pérez-Curiel, Concha; Domínguez-García, Ricardo; Jiménez-Marín, Gloria (2021). "Public sphere and misinformation in the U.S. election: Trump's audience and populism indicators in the Covid-19 context". Journalism and media, n. 2, pp. 335-350.

https://doi.org/10.3390/journalmedia2030020

Pérez-Curiel, Concha; Limón-Naharro, Pilar (2019). “Political influencers. A study of Donald Trump's personal brand on Twitter and its impact on the media and users". Communication and society, v. 32, n. 1, pp. 57-76.

https://doi.org/10.15581/003.32.1.57-76

Pérez-Curiel, Concha; Rivas-de-Roca, Rubén (2021). "Realities and challenges of a democracy in crisis. Impact of desinformation and populism on the media system". In: Rocha, Álvaro; Barredo-Ibáñez, Daniel; López-López, Paulo-Carlos; Puentes-Rivera, Iván (eds.). Communication and smart technologies, ICOMA 2021. Smart innovation, system and technologies, v. 259. Singapore: Springer. ISBN: 9789811657917

https://doi.org/10.1007/978-981-16-5792-4_10

Pérez-Curiel, Concha; Rivas-de-Roca, Rubén; García-Gordillo, Mar (2021). “Impact of Trump’s digital rhetoric on the US elections: A view from worldwide far-right populism”. Social sciences, v. 10, n. 152.

https://doi.org/10.3390/socsci10050152

Pérez-Curiel, Concha; Velasco-Molpeceres, Ana-María (2020). "Impacto del discurso político en la difusión de bulos sobre Covid-19. Influencia de la desinformación en públicos y medios". Revista latina de comunicación social, n. 78, pp. 65-97. https://www.doi.org/10.4185/RLCS-2020-1469 
Pew Research Center (2020). "Sharp divisions on vote counts, as Biden gets high marks for his post-election conduct". Pew Research Center, 20 November.

https://www.pewresearch.org/politics/2020/11/20/sharp-divisions-on-vote-counts-as-biden-gets-high-marks-for-hispost-election-conduct

Pew Research Center (2021). "Appendix A: Grouping outlets by audience ideology and grouping survey respondents by media diet". Pew Research Center, 28 April.

https://www.journalism.org/2021/04/28/biden-administration-100-days-appendix-a-grouping-outlets-by-audienceideology-and-grouping-survey-respondents-by-media-diet

Romero-Rodríguez, Luis M.; De-Casas-Moreno, Patricia; Torres-Toukoumidis, Ángel (2016). “Dimensions and indicators of the information quality in digital media". Comunicar, v. 24, n. 49, pp. 91-100.

https://doi.org/10.3916/C49-2016-09

Rost, Alejandro; Bernardi, María-Teresa; Bergero, Fabián (2016). Periodismo transmedia. La narración distribuida de la noticia. Neuquén: Publifadecs. ISBN: 9789871549993

http://rdi.uncoma.edu.ar//handle/123456789/15341

Roth, Yoel (2018). "Automation and the use of multiple accounts". Twitter. Developer blog, 21 February. https://blog.twitter.com/developer/en_us/topics/tips/2018/automation-and-the-use-of-multiple-accounts.html

Rúas-Araújo, Xosé; Mazaira, Andrés; Rodríguez-Vázquez, Ana-Isabel (2018). “Nuevos medios y medios tradicionales en la red. Espacios de opinión e interacción política en la era Trump”. Icono 14, v. 16, n. 1, pp. 86-113.

https://doi.org/10.7195/ri14.v16i1.1118

Salaverría, Ramón; Buslón, Nataly; López-Pan, Fernando; León, Bienvenido; López-Goñi, Ignacio; Erviti, María-Carmen (2020). "Desinformación en tiempos de pandemia: tipología de los bulos sobre la Covid-19". El profesional de la información, v. 29, n. 3.

https://doi.org/10.3145/epi.2020.may.15

Sánchez-Saus, Marta (2018). “Análisis de palabras clave en comunicación para el desarrollo y el cambio social: el caso de \#comunicambio en Twitter". Cultura, lenguaje y representación, n. 19, pp. 119-139.

https://doi.org/10.6035/clr.2018.19.7

Sanz-Blasco, Rubén; Carro-de-Francisco, Cristina (2019). "Susceptibilidad cognitiva a las falsas informaciones". Historia y comunicación social, v. 24, n. 2, pp. 521-531.

https://doi.org/10.5209/hics.66296

Schulte-Cloos, Julia; Leininger, Arndt (2021). "Electoral participation, political disaffection, and the rise of the populist radical right". Party politics.

https://doi.org/10.1177/1354068820985186

Silverman, David (2016). Qualitative research. London: SAGE. ISBN: 1473916569

Smyrnaios, Nikis; Rebillard, Franck (2019). “How infomediation platform took over the news: a longitudinal perspective". The political economy of communication, v. 7, n. 1, pp. 30-50.

https://www.polecom.org/index.php/polecom/article/view/103

The economist (2020). "Only a quarter of Republicans believe Donald Trump should concede". The economist, 19 November.

https://www.economist.com/graphic-detail/2020/11/19/only-a-quarter-of-republicans-believe-donald-trump-shouldconcede

The New York Times (2021). "Republican ties to extremist groups are under scrutiny". The New York Times. https://www.nytimes.com/2021/01/29/us/republicans-trump-capitol-riot.html

The Washington Post (2020). “Exit poll results and analysis for the 2020 presidential election”. The Washington Post, 14 December.

https://www.washingtonpost.com/elections/interactive/2020/exit-polls/presidential-election-exit-polls

Van-Aelst, Peter; Strömbäck, Jesper; Aalberg, Toril; Esser, Frank; De-Vreese, Claes; Matthes, Jörg; Hopmann, David; Salgado, Susana; Hubé, Nicolas; Stępińska, Agnieszka; Papathanassopoulos, Stylianos; Berganza, Rosa; Legnante, Guido; Reinemann, Carsten; Sheafer, Tamir; Stanyer, James (2017). "Political communication in a high-choice media environment: a challenge for democracy?”. Annals of the International Communication Association, v. 41, n. 1, pp. 3-27. https://doi.org/10.1080/23808985.2017.1288551

Van-Dijk, Teun A. (2015). "Critical discourse studies. A sociocognitive approach”. Methods of critical discourse studies, v. 3, n. 1, pp. 63-85.

http://www.discourses.org/OldArticles/Critical\%20Discourse\%20Studies.pdf 
Vázquez-Cano, Esteban; Fombona, Javier; Bernal, César (2016). “Análisis computacional de las características ortotipográficas y paralingüísticas de los tweets periodísticos”. El profesional de la información, v. 25, n. 4, pp. 588-598. https://doi.org/10.3145/epi.2016.jul.08

Verdú, Yolanda (2009). Sesgo y encuadre en las noticias de televisión. Mecanismos de manipulación periodística a propósito del urbanismo y del agua en los informativos de Canal 9. Tesis doctoral, Universitat de València.

Waisbord, Silvio (2018). "Truth is what happens to news: on journalism, fake news, and post-truth". Journalism studies, v. 19, n. 13, pp. $1866-1878$.

https://doi.org/10.1080/1461670X.2018.1492881

Waisbord, Silvio; Amado, Adriana (2017). "Populist communication by digital means: presidential Twitter in Latin America information". Communication and society, v. 20, n. 9, pp. 1330-1346.

https://doi.org/10.1080/1369118x.2017.1328521

Wason, Peter C. (1960). "On the failure to eliminate hypotheses in a conceptual task". Quarterly journal of experimental psychology, v. 12, n. 3, pp. 129-140.

https://doi.org/10.1080/17470216008416717

Wodak, Ruth (2015). The politics of fear: What right-wing populist discourses mean. Londres: Sage. ISBN: 1446247007

Woolley, Samuel C.; Howard, Philip N. (2017). Computational propaganda worldwide: executive summary. Working paper. Oxford: Computational propaganda research project.

http://comprop.oii.ox.ac.uk/wp-content/uploads/sites/89/2017/06/Casestudies-ExecutiveSummary.pdf

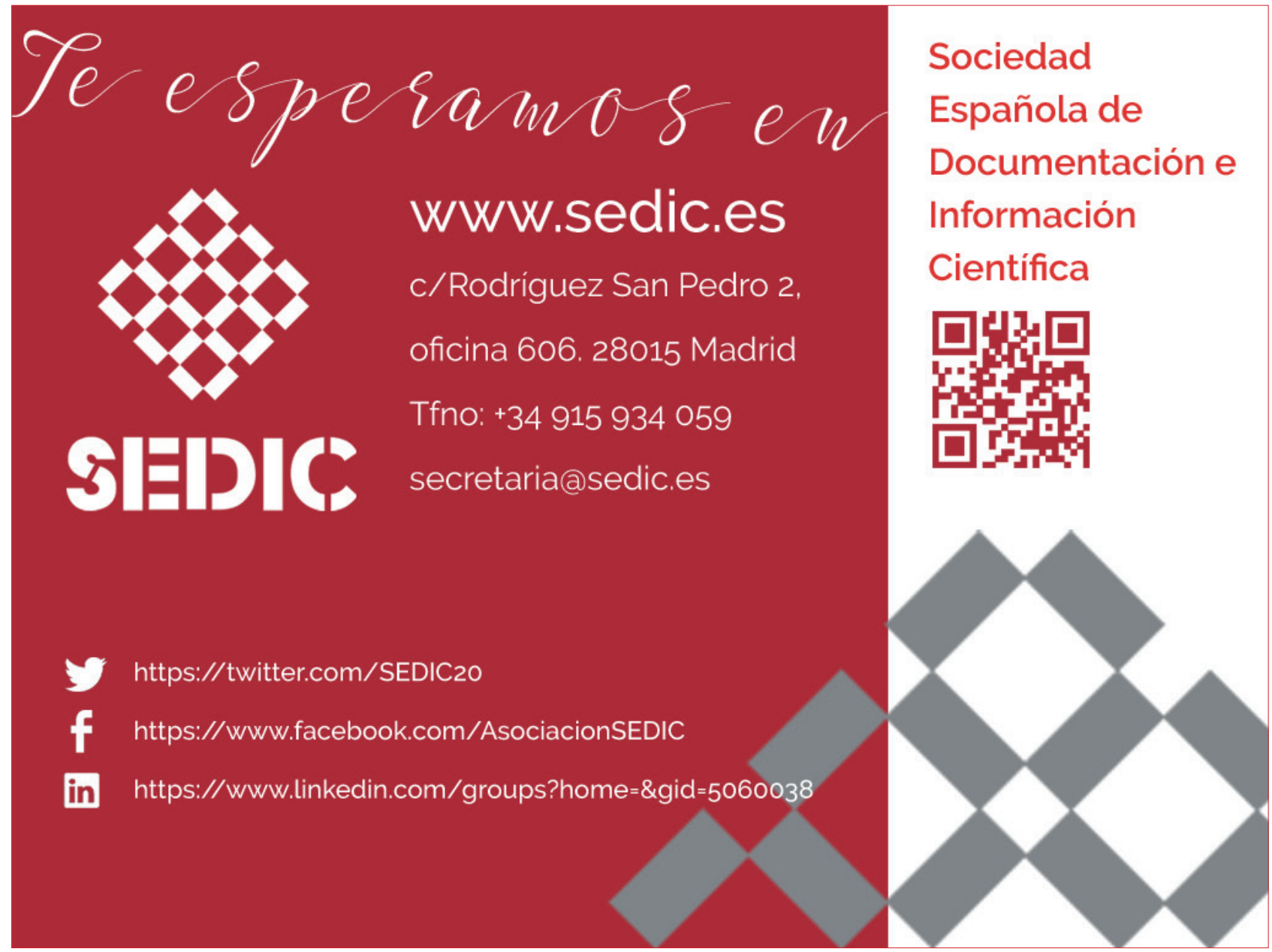

